Article

\title{
Teachers Co-Designing and Implementing Career-Related Instruction
}

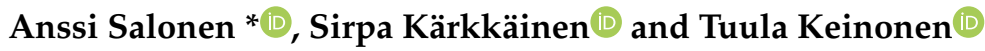 \\ School of Applied Educational Science and Teacher Education, University of Eastern Finland, \\ Joensuu P.O. Box 111, 80100 Joensuu, Finland; sirpa.a.karkkainen@uef.fi (S.K.); tuula.keinonen@uef.fi (T.K.) \\ * Correspondence: anssi.salonen@uef.fi
}

Received: 9 September 2019; Accepted: 14 October 2019; Published: 16 October 2019

\begin{abstract}
Teachers encounter the challenge of how to provide students adequate awareness of science-related careers. Therefore, innovative teaching material for promoting science-related careers needs to be designed. Educational innovations can be successful if teachers experience ownership and agency towards the designed teaching material. In this case study, a multi-professional group of two science teachers, a researcher, and a dentist co-designed instruction including a career presentation and relevant information about field-specific education and skills needed by a professional in that field. We refer to this as career-related instruction. The designed learning unit includes a scenario, inquiries and career-related activities. Teachers' perceptions about co-designing and implementing the learning unit in science education are examined as well as students' perceptions about the scenario. Data consists of teacher interviews and discussions and student questionnaires. A content analysis reveals the teachers' high ownership and agency in co-designing the instruction, which was relevant, interesting and informative for students. It was easy for teachers to implement the learning unit even though they were not involved in every phase of the design process. We conclude that by strengthening teachers' ownership and agency through multi-professional co-designing, relevant and interesting career-related instruction can be designed and implemented.
\end{abstract}

Keywords: co-designing; instruction; learning unit; agency; ownership; careers; science education; teacher professional growth

\section{Introduction}

One of the challenges in school science is how to introduce science-related careers to students. Students need knowledge about different careers to be able to make informed decisions on their educational and career paths. Students are not aware of the many available career options and know few professionals working in science, technology, engineering and mathematics (STEM) fields [1,2]. At the same time, teachers struggle to introduce and use careers in science education [3] and provide students with adequate awareness of careers related to science. Even experienced teachers need to develop their pedagogy, acquire new knowledge, skills and methods, alter and adopt new teaching and novel instructional designs [4].

Imposing new educational innovations on teachers in a top-down approach is not effective [5]. Particularly in countries where teachers have high autonomy and traditionally low control from authorities [6]. Top-down approaches have been unsuccessful because the teacher's existing personal domain is not acknowledged, and they are just set in a role to implement learning units developed by someone else [7]. Conversely to the top-down approach, the bottom-up approach increases teachers' ownership of curriculum innovations [5]. Such innovations succeed when teachers feel that the innovation belongs to them instead of only imposing it on them [8]. Using the best aspects of both top-down and bottom-up approaches helps to introduce new philosophies, ideas and learning 
units to in-service teachers and facilitates finding ways to make teachers' existing knowledge and beliefs explicit [9]. For this, multi-professional co-designing of educational innovations offers one solution. Educational co-designing is defined as creating new or adapting existing curricular activities in collaboration with peers, experts and career professionals with up-to-date insights, and other stakeholders' and students' ideas [10]. Lately, a few studies have successfully brought together teachers and scientists as partners in science education [11], also with the help of technology [12]. These partnerships in educational planning help teachers to understand the relevance and usefulness of educational innovations and provide new competencies in instructional planning and implementation for teachers [13].

During the interaction in co-designing, teachers can incorporate their views about ownership and agency in relation to instruction under design and concrete teaching material [14]. Furthermore, teachers' sense of ownership and agency is important in designing and implementing a successful educational innovation [15]. Therefore, investigating teachers' ownership and agency helps to understand how teachers reflect on co-designing educational innovation, to students' perceptions and how to continue designing instructional methods further.

In this case study, two teachers, a researcher, and a scientific professional co-designed a career-related learning unit and a corresponding scenario named "Coal to teeth" dealing with activated carbon and dental health and care. This study seeks to understand how a multi-professional group co-designs science teaching that is both a valuable tool for teachers, but also relevant and interesting for students. Therefore, this study aims to examine the design process of career-related instruction with the following research questions:

- What are the teachers' perceptions about the co-designed learning unit in terms of ownership and agency?

- How do the students respond to the scenario introduced at the beginning of the learning unit?

\section{Theoretical Framework}

\subsection{Ownership and Agency}

Ownership and agency are closely related to a teacher's identity. Ownership is a mental state of welcoming, accepting and possessing ideas such as educational innovations as part of the owner's identity [16]. Teachers are more likely willing to invest their resources in the success of educational innovation when they feel ownership of the process and can see what is important in the innovation [17]. If teachers support the new ideas of the innovation and feel that a change is necessary, they invest their resources in designing and implementing the innovation [18]. It is important that as the implementers of educational innovation, teachers identify themselves with the innovation and communicate about it in their professional community [16]. In summary, ownership can be recognized by teachers' needs and support for the innovation and communication about the innovation [14]. Ownership develops when teachers can co-construct knowledge and educational improvements, they have suitable support and practices to make these efforts and the value of their collective expertise and knowledge is recognized [19].

Teachers might see that educational innovations coming from the outside reduce their level of control [20] and limit their autonomy to define what and how to teach [21]. Therefore, teachers experiencing agency in their career means that they feel in control of their actions [22] and that their goals, interests and motivation guides their work-related choices [23]. To freely make these choices, teachers need a high level of autonomy [24]. Thus, both school context, co-workers and teachers themselves shape experiences of agency. When teachers are implementing new educational innovations, they accommodate the process and adjust their work according to the innovation [14]. It increases teachers' sense of agency, when their goals match their beliefs about the benefits of the innovation. In addition, teachers linking an innovation's successes and failures to themselves instead of pointing out external factors, shows a strong sense of agency towards the innovation [25]. The 
amount of teachers' experienced agency within their work makes a difference in their response to the innovation [18]. Therefore, to find out teachers' experiences of agency, their own and workplace goals need to be identified and compared to inform their choices.

Teachers are interested in the salient outcomes of the instruction they implement [26]. Therefore, they are also curious about the latest educational knowledge and skills to enable students to engage in science learning. In science education, the change from teacher-and content-centered approaches to context-based approaches and collaboration with industry and community has provided promising results in promoting students' motivation and feel of relevance for learning science and increasing uptake of science studies and careers $[27,28]$.

\subsection{Science Education Promoting Career Awareness}

Science career stereotypes still exist $[29,30]$ and school science fails to eliminate these stereotypes and emphasize women's role in science [31]. Therefore, science education should focus on introducing, not only well-known careers such as chemists and physicians, but also less visible science occupations in everyday life [32]. Insufficient awareness of science-related careers and scientific work together with underestimating one's own science abilities reduces students' likelihood of pursuing science studies and careers [1]. In addition, interest, engagement and relevance influence students' future career aspirations [33]. Several studies [34-36] conclude that school science has an impact on students' future career choices. In addition, Dewitt and Archer [37] argue that it is not always the positive attitudes that drive students towards scientific careers. They suggest that differences in 'science capital' helps to explain career aspirations. Hence, students need to acquire both scientific competencies but also information about careers through education.

Students feel that learning science subjects, particularly chemistry, is remote and irrelevant for their everyday life outside school and their future role in society [38]. However, students tend to think that science-related careers are important, and it is necessary that someone else choose science studies and careers even if they are not interested in that [39]. Nevertheless, without correcting students' awareness of science careers, relevance of science and interest in studying science, the problem of students not pursuing science studies and careers will most likely remain.

The number of students making informed decisions to choose STEM studies and careers can be increased with students' early awareness and accurate perceptions of STEM careers [40,41]. For example, socio-scientific issues bring together scientific knowledge with real-world and everyday topics in a social context [42]. Several studies, particularly outside Europe, introduce attempts to build teacher-scientist and student-scientist partnerships to improve student satisfaction, interest and engagement in science studies and careers [43-45]. In these partnerships, authentic experiences of work in science enhance students' attitudes and understanding about careers and the latest scientific knowledge from the field $[45,46]$. In addition, through the partnerships, teachers can acquire new pedagogical tools, knowledge and more positive attitude towards professionals in the field. Successful partnerships usually involve either scientists visiting the classroom or students visiting authentic workplaces. However, there are critical restrictions to be considered in these partnerships: access to experts, resources, educational standards and curriculums, and lack of supporting materials [47]. Therefore, not all attempts have been successful and there is a request for a new kind of instructions to be developed [43]. These school-industry/community partnerships are particularly new in Finnish science education. Career preparation has traditionally [48] been seen as the responsibility of student counselling until the curriculum reform taken into practice in 2016 when career preparation was included under every subject [49]. Therefore, teachers now struggle creating the partnerships and career-related instructions to promote students' career awareness.

Another way to increase students' awareness of science-related careers, relevance of science and interest in science is using real-world contextual issues involving science and technology discussions [50,51]. The scenarios are educational innovations that start science lessons and link science content with everyday life [52]. The scenarios also initiate motivational scientific thinking and 
the science learning process [53]. Hence, the point of the scenario is to not only introduce scientific knowledge, but also highlight the relevance of the topic, guide towards participatory activities such as inquiries, expressing opinions, and socio-scientific decision making. In this study, the designed scenario has a career context. This kind of career-based scenario starts the learning unit and aims to present careers and scientists in multiple ways, for example, career stories, videos, interviews and visits, to increase students' interest and motivation towards science learning. Scientific inquiries and other learning activities should take place after the scenario to frame the learning unit. Thus, students become more aware about the scientific processes that are important for working professionals [54].

\section{Methods}

The context of the study is the EU project MultiCO with five participating countries. The project's aim is to promote scientific career awareness and engagement in science learning using career-based scenarios. The overall methodology of the MultiCO project follows the design-based research (DBR) approach [55] in order to develop how careers could be introduced to the students in science education. In the project, collective case studies are conducted in participating countries to develop a rich understanding but also practical implications and solutions for the problem [56]. The intention of a case study is to investigate real-life interactions of events and human behavior in unique contexts [56]. These interactions are operated by several variables and thus the use of multiple data sources is suggested for case studies even though the intention of a case study is not to provide generalized results [56]. The present case study with mixed methods, both quantitative and qualitative, provides deeper information and understanding about the co-designing process of science education teaching material in terms of teachers' ownership and agency, and how students respond to this designed material (Figure 1).

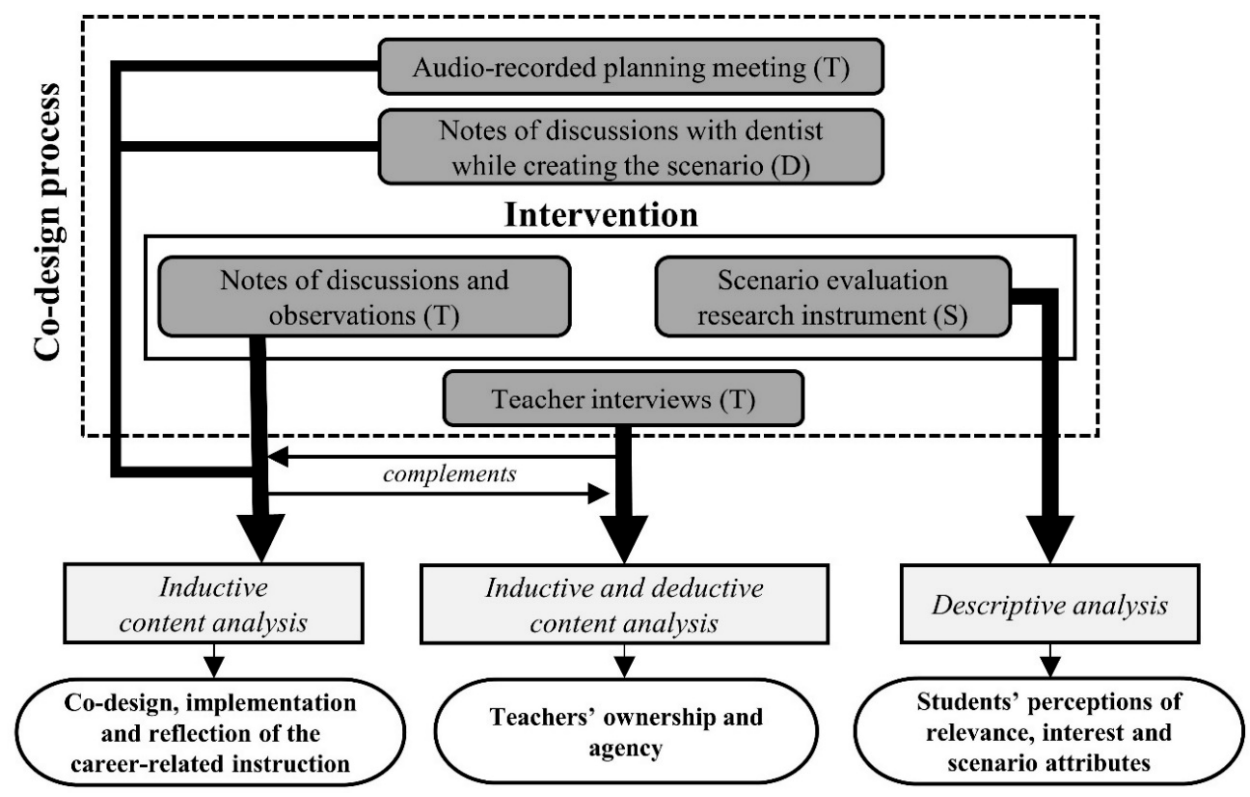

Figure 1. Overall methodology of the study $(\mathrm{T}=$ teacher data; $\mathrm{S}=$ student data; $\mathrm{D}=$ dentist data).

The designed learning unit was implemented as an intervention (Table 1), which consisted of four lessons (total of $315 \mathrm{~min}$ ) including a career-based scenario, inquiries and career-related activities. Teachers' role in the first lesson was to start a discussion about the career and the assignment, which the dentist provided. The first lesson's inquiries were instructed by the teachers but once started their role changed to guiding the students through the inquiry steps. After the inquiries the teacher reminded the students about the dentist's assignment again and gave hints and helped them to find out how they could create their own experiments for the next time. Based on the students' ideas of experiments, the 
teachers prepared inquiry equipment and materials for the next lessons. During the lessons, teacher's role was to provide guidance in difficult phases. Their main attention was on low achieving students. Teachers frequently reminded the students that the dentist needs the results of these inquiries and therefore the students should be precise in their experiments. It was up to teacher to decide when to show the additional interview video. With one group it was during the inquiries and with others in the end of the lesson three. In the last lesson teacher provided students with the equipment and help with the technology the students used. Moreover, their role was to lead the discussion after the dentist's video response to the students' results.

Table 1. Intervention description.

\begin{tabular}{|c|c|}
\hline Unit Phase & Content and Aims \\
\hline \multicolumn{2}{|r|}{ Lesson 1 (90 min) } \\
\hline Scenario & $\begin{array}{l}\text { Video presenting a patient visiting a dentist and asking her about carbon toothpaste. } \\
\text { Later in the video, the dentist gives the students the following task: } \\
\text { - would you suggest the toothpaste including activated carbon to the patient who } \\
\text { wants to get whiter teeth and compare it with other toothpastes? }\end{array}$ \\
\hline Inquiries & $\begin{array}{l}\text { - The students worked in groups of 3-4 persons and tested how activated carbon } \\
\text { can be used to absorb colors of tea, water with colorants and a solution of } \\
\text { copper sulphate. } \\
\text { - Students plan their own experiments. }\end{array}$ \\
\hline \multicolumn{2}{|r|}{ Lessons 2 and 3 (45 and $90 \mathrm{~min})$} \\
\hline Inquiries & $\begin{array}{l}\text { - The students tested the abrasiveness of four different toothpastes by scrubbing the } \\
\text { toothpaste on metal sheets and silver spoons and observing the different scratches } \\
\text { and marks the toothpaste left on the oxidized metal objects. Some toothpaste } \\
\text { manufacturers report the relative dentin abrasion (RDA) value of abrasiveness, } \\
\text { but it is not mandatory. Students were guided to think about why some of the } \\
\text { manufacturers did not want to report the value. } \\
\text { The students examined the toothpaste package for fluorine and other ingredients } \\
\text { such as saccharin concentration and if the toothpaste was recommended by the } \\
\text { dentist association or if it was clinically proven. } \\
\text { The students tested the carbon toothpaste to examine the taste, texture } \\
\text { and abrasiveness. }\end{array}$ \\
\hline Career-related activities & $\begin{array}{l}\text { The career presentation video was presented to the students introducing a dentist's } \\
\text { personal career development from high school science studies to becoming a dentist, } \\
\text { doctor and finally to her current work specializing in plastic surgery. She was asked, } \\
\text { e.g., about her own experiences of science studies and what motivates her in her work. }\end{array}$ \\
\hline \multicolumn{2}{|r|}{ Lesson $4(90 \mathrm{~min})$} \\
\hline $\begin{array}{l}\text { Bridged inquiries and } \\
\text { career-related activities }\end{array}$ & $\begin{array}{l}\text { The students filled in a laboratory form of their inquiries and created a video reporting } \\
\text { their suggestion. The video was sent by email to the dentist. Finally, a video message } \\
\text { from the dentist was presented thanking the students for their results and providing } \\
\text { them accurate information about teeth whitening with hydrogen peroxide. }\end{array}$ \\
\hline
\end{tabular}

\subsection{Participants}

The participants in this study were two female science teachers and their three 8th grade science groups with a total of 41 students, aged 14-15 years. In addition, a professional female dentist and a researcher were involved in co-designing the learning unit.

\subsection{Data Collection}

Data was collected before, during and after the intervention (Figure 1). Before intervention, teachers and the researcher had an audio-recorded planning meeting $(90 \mathrm{~min})$ starting the design process of the learning unit. Furthermore, notes were taken on the discussions with the professional dentist while creating the scenario and career-related activities. During the intervention, the data from 
teachers was collected with informal conversational interviews (discussions), spontaneously asking questions in a natural interaction. Usually these discussions lasted for 5-10 min.

After the scenario video, the students answered a validated scenario evaluation research instrument (SERI) $[57,58]$ questionnaire, which includes three dimensions of relevance: individual, societal and vocational [59], interest and scenario attribute variables. The questionnaire included 28 Likert items on a 4-point scale. Four items had additional open-ended question asking students' to give reasons for their answer: "The topic of the scenario is interesting", "The knowledge in the scenario is useful for me", "I liked the scenario" and "This scenario made me interested to learn more about the topic".

After the intervention, teachers were interviewed. These retrospective interviews were semi-structured including themes: (1) Designing the instruction and links to science curriculum, (2) Career awareness and working life skills, (3) Students' interest, engagement and relevance of science, (4) Reflecting the implementation. In contrast with the discussions, this type of interview is planned with open-ended questions and other questions might emerge from the dialogue [60]. The interviews lasted for 103 and $82 \mathrm{~min}$.

\subsection{Data Analysis}

Before analysis, audio-record of planning meeting, notes and interviews were transcribed. All teacher data were analyzed using content analysis (cf. [61]). The analysis included two main parts. In the first part, we used inductive approach of content analysis to study teachers' perceptions about the co-design process and implementation of the learning unit. Audio-record and notes were complemented with teacher interviews.

In the second part of the analysis, the interviews acted as the main data for teachers' ownership and agency. However, the previously collected audio-record before, and notes of observations and discussions during the intervention provided more detailed and accurate information about the teachers' ownership and agency during the emerged situations. This content analysis combined both inductive and deductive approaches. Based on reading and making sense of these transcriptions, signs of teachers' ownership and agency was found in inductive categorization and grouping. The authors decided that since teacher's ownership and agency are widely studied, a deductive approach was used to conceptualize the categories of teachers' perceptions. Thus, the categories for ownership and agency are displayed in Table 2, derived from previous research. We found the following categories for ownership: supporting the design or ideas [17], mental/physical effort [62], identifying with the instruction [16] and need for change [18]. For agency we found categories: successes and failures [25], accommodation [14], autonomy [21] and feel of control [20,22].

Table 2. The deductive approach to form categories of teachers' ownership and agency in this study.

\begin{tabular}{cc}
\hline Ownership & \\
\hline $\begin{array}{c}\text { Supporting the design or ideas } \\
\text { Mental/physical effort } \\
\text { Identifying with the instruction } \\
\text { Need for change }\end{array}$ & Breiting [17] \\
\hline Agency & Struckman \& Yammarino [62] \\
Pierce et al. [16] & Ketelaar [18] \\
\hline Successes and failures & Marshall \& Drummond [25] \\
Accommodation & Ketelaar et al. [14] \\
Autonomy & Allen \& Penuel [21] \\
Feel of control & Konopasky \& Sheridan [20]; Metcalfe \& Greene [22] \\
\hline
\end{tabular}

In addition to the content analysis of teacher data, we present the descriptive statistics from the students' evaluation questionnaire in the results to report how the students responded to the scenario. 


\subsection{Validity, Reliability and Ethical Consideration}

Each type of measure, for example, notes, interviews and questionnaires, have strengths and weaknesses. Combining instruments is a way to triangulate perceptions as they occur [63]. Interviews are always retrospective, and participants need to reflect on what they have experienced. Therefore, to increase the validity, discussions and notes were also taken during the co-design process and implementation. We used a validated instrument to examine students' perceptions.

The questionnaire items were translated into Finnish so the students could answer in their native language. Multiple researchers did the translations for the questionnaire items and quotations with care to preserve the intended meaning of the sentences.

The teachers were experienced, and the way of teaching was familiar to them. Furthermore, the researcher worked in close cooperation with the teachers. The students were familiar with the presence of the researcher, so they worked normally, and their behavior was natural during the intervention. These aspects increase the reliability of collected data.

Before the project was launched, the institution's committee on research ethics was consulted and they agreed there was no need for further ethical review of the research by the MultiCO project. In addition, the project has followed the ethical regulations and instructions on EU, national and institutional levels. The EU has received ethical statements before and during the project's progress. Thus, the project and experiments were performed in compliance with the authors' institute's policy on ethics, national and international laws, and guidelines such as the Personal Data Act. Teachers participated voluntarily in the research project. The autonomy of student participants was respected: participation was voluntary, and consent was asked from students' guardians, teachers, schools and school administrators. Privacy and data protection were taken into account; teacher identification information was removed during transcription and anonymity of the students was secured by collecting questionnaire data anonymously. Data was made available only for the use of the research group. Based on privacy principles, the school name and region are not included in the study.

\section{Results}

First, we present the co-design process, implementation and reflection on the career-related instruction. Second, teachers' perceptions about their feel of ownership and experiences of agency are presented. Last, we provide the results from the students' questionnaire answers.

\subsection{Co-Design, Implementation and Reflection of the Career-Related Instruction}

The teachers had already during the MultiCO project planned two career-based scenarios and corresponding learning units. Now the teachers perceived something new that had to be tested in the scenarios because they still struggled to implement an interesting and relevant way to introduce careers in science education. After the first two longer learning units, they wanted the next scenario and following inquiries to be shorter to keep the whole unit motivating to the students. The idea for the scenario and learning unit dropped into their mailbox: "We found this pharmacy advertisement with a picture of black toothpaste". The teachers discussed this new health product, carbon toothpaste, with some of their students and had the idea to use the toothpaste in the scenario (Table 3).

The teachers had an idea of the kind of scenario they wanted implemented during their starting period of organic chemistry and carbon. They wanted the scenario to combine information about health issues, chemistry and the career of a dentist and her explanations about the health issues with teeth, e.g., cavities, fluorine and taking care of teeth. They perceived that they could easily link these issues with their earlier periods of acids and safety issues in chemistry. In the planning meeting, the teachers pointed out that they were willing to test a scenario including a career interview video, or at least a picture of a real dentist. First, they discussed that the careers would be a dentist and a pharmacist, but later they decided that only a dentist would be introduced in this scenario to keep it simple: "I think we discussed about including a chemist but we just had the chemist in previous (scenario). Then we, I think, decided 
that a pharmacist and a dentist but for some reason, maybe (other teacher name) remembers why only dentist was chosen"; "We agreed to use only one career here as it was decided that this one (learning unit) is a short and simple one". Teachers perceived that the dentist career could also promote women in science.

Table 3. Participation in design phases.

\begin{tabular}{ccccc}
\hline Design Principles & Teachers & Researchers & Dentist & Students \\
\hline Idea & $\mathrm{X}$ & & & $\mathrm{X}$ \\
Curriculum content & $\mathrm{X}$ & & & \\
Socio-scientific issue & $\mathrm{X}$ & $\mathrm{X}$ & & \\
Career with shared context & $\mathrm{X}$ & $\mathrm{X}$ & & \\
\hline Career-based scenario & & & \\
\hline Designing the scenario & $\mathrm{X}$ & $\mathrm{X}$ & $\mathrm{X}$ & \\
Creating the scenario & $\mathrm{X}$ & $\mathrm{X}$ & \\
Re-designing the scenario & & & \\
\hline Inquiries and career-related activities & $\mathrm{X}$ & & \\
\hline Designing scientific inquiries & $\mathrm{X}$ & $\mathrm{X}$ & $\mathrm{X}$ & \\
Designing career-related activities & $\mathrm{X}$ & & $\mathrm{X}$ \\
\hline Reflection and evaluation & & & \\
\hline
\end{tabular}

Teachers explained how difficult it is to integrate careers in science education. Teachers did not have a professional network outside of education from which to find professionals. They also perceived that they have a lack of knowledge about what careers there might be linked to the science curriculum and inquiries. They also pointed out that even if it is included in their work through the new curriculum, there is no additional resources like time or funding: "It takes time and during normal working hours it is not possible to start this without help". Therefore, they wanted to involve a real professional in designing the instruction to combine science knowledge from the dentist and her explanations about the chemistry issues related to dentistry.

The researcher and the dentist created the scenario based on the ideas of the teachers. The dentist was open for any ideas but wanted to keep it as professional as possible because she felt responsible for sharing information and she also worried about her professional appearance as can be seen in her following quote: "You should keep to the facts, as the profession is highly appreciated and you do not want to look like an amateur if this goes public".

The dentist understood how to raise students' attention and what kind of information would be interesting for them. Her young patients were always interested about the equipment used in dentistry, so they were included in the video. The dentist made it really clear in the video that even the most expertized health professionals like doctors and dentists need daily help from scientists and other professionals. She also had an idea that in her interview she tells about her life outside work such as hobbies and what other books than medical books she likes to read. In addition, the dentist behaved formally when talking to the patient, but changed her behavior when she contacted the "laboratory" through video message. Creating the scenario took two hours of her time, but she experienced that it was worth it if at least a few students would learn something new about her profession and gain interest in her field. It was her idea to state that the patient had cavities so she could include more general information about dental care in the video.

At the beginning of the implementation of the learning unit, teachers presented the scenario video to the students. After that the teachers started a discussion about what the students just saw and the problems the dentist pointed out. The first inquiry introducing activated carbon followed the discussion. After the first lessons, teachers realized a problem. The scenario did not explain the connection with the toothpaste and activated carbon clear enough and they did not include it in the discussion after the video either. After the first inquiry about activated carbon, the teachers introduced 
the toothpaste. They explained that it included activated carbon similar to what they had used in a previous inquiry.

The teachers supposed that discussing the toothpaste with the students before going through the first inquiries could have helped the students link the properties of activated carbon with the toothpaste and whitening of teeth. However, it was important to them to avoid interfering with the students' creativity and imagination during the inquiries:

"You are not supposed to interfere too much when the students start to think about their own inquiries and activities. If they want to test something even outside your field of expertise you should just provide them the tools for that." T1

The teachers realized that it was good that the career of a dentist is somehow familiar to the students, but it would be good to expand the viewpoint from one career to a field of industry:

"Something familiar and safe. If the career is totally unknown to the students, they might not learn anything from it. However, it could be interesting to give something new.", T1; "A dentist just works with the patient, but what about everything in the background? There is technology beyond dentistry and several opportunities for development as well." T2

The teachers perceived that this scenario was appropriate to start a new period in science teaching. It was motivational and something different compared to earlier lessons. The teachers were also interested in scientific topics that could be raised via the dentist's work and how these topics could be used to collaborate with other teachers and subjects.

\subsection{Teachers' Ownership and Agency}

Teachers' perceptions about the instruction were categorized in the light of ownership and agency (Table 4). The key findings from each category are presented in the order seen in Table 4 . In general, during designing, implementing and reflecting, both teachers experienced ownership and agency. They also acknowledged the benefit of co-designing science instruction as a tool for increasing their knowledge outside their area of expertise. In addition, the teachers felt this was a suitable way for them to emphasize co-teaching and co-planning of teaching.

Table 4. Categorization of teachers' perceptions about the instruction in the light of ownership and agency.

\begin{tabular}{lcc}
\hline \multicolumn{1}{c}{ Categories } & $\mathbf{n}$ & Examples of Data \\
\hline Supporting the design or ideas & 12 & $\begin{array}{l}\text { "It is good that someone else gives the tasks (to students) sometimes } \\
\text { instead of a teacher.", T1 }\end{array}$ \\
\hline Mental and physical effort & 5 & $\begin{array}{l}\text { "It was easy and fun just to implement something pre-made. Made my } \\
\text { job a little easier for once", T2 }\end{array}$ \\
\hline Identifying with the instruction & 5 & $\begin{array}{c}\text { "I have added this as one of my regularly implemented curriculum } \\
\text { activities", T2 }\end{array}$ \\
\hline Need for change & 4 & $\begin{array}{l}\text { "Careers are hard to include in chemistry education.", T1; } \\
\text { "Something old with a new twist is needed", T2 }\end{array}$ \\
\hline Successes and failures & 11 & $\begin{array}{c}\text { Agency } \\
\text { "Any mistakes in the scenario or inquiries were not anyone's fault. It } \\
\text { happens when you create or test something new.", T1 }\end{array}$ \\
\hline
\end{tabular}


Table 4. Cont.

\begin{tabular}{lll}
\hline Categories & Examples of Data \\
\hline Accommodation & $6 \begin{array}{c}\text { "It was easy to implement and to go with the flow with the students.", T1 } \\
\text { "I did not see any reason not to follow the collaboratively designed } \\
\text { learning unit.", T2 }\end{array}$ \\
\hline Autonomy & $\begin{array}{l}\text { "I think after all, we implemented the learning unit just the way we } \\
\text { designed and wanted.", T2 }\end{array}$ \\
Feel of control & $\begin{array}{l}\text { "The scenario was ready so late that it made me a little unsure of what } \\
\text { "After all, I did not see any reason for not following the designed learning } \\
\text { unit. Of course, with minor changes I made along the way.", T1 }\end{array}$ \\
\hline
\end{tabular}

\subsubsection{Ownership}

Teachers' ownership in relation to the instruction varied in different phases of co-designing. Teachers supported most of the ideas their colleague, the researcher or the dentist had. They perceived that the topic was relevant for the students. Teachers' support for the learning unit became obvious when they acted along the designed learning unit activities. For example, all the videos were premade, but they introduced them to students as a real connection with the dentist to emphasize the link with schoolwork and professional work. Teachers also perceived it was easy to link the learning unit with the existing curriculum. Teachers appreciated that a professional set the problem and gave the assignment instead of a teacher.

Designing the instruction required teachers' mental effort in planning meetings. Their mental or physical effort was not needed in creating the scenario and they perceived this as relieving. During the intervention, teachers' mental and physical effort was obvious as they were the practical implementors of the learning unit. Teachers appreciated the effort the researcher and dentist had put toward creating the scenario, even though they had to re-design parts of the learning unit to fit in the class context.

Teachers identified with the instruction and acknowledged its benefits for them and the students. During co-design and implementation processes, they worked in close collaboration. A sign of their identification with the instruction is also that once it was implemented, the teachers discussed and shared the learning unit with their peers in school and the local area. According to the teachers, they sometimes do this, but only if they see it as valuable for others. The teachers have also implemented the learning unit several times in other classes and continued to re-design it together.

So far, the teachers had wanted to use their own scenarios instead of premade or existing ones. Now, both teachers expressed there was a need for a change as they previously unsuccessfully included careers in science education.

\subsubsection{Agency}

Teachers' agency focused on their critical evaluation of the successes and failures of the learning unit. They perceived that the scenario, inquiries and career-related activities were connected to each other successfully. They were also eager to reflect on the design and practice of the instruction to make the learning unit better. For example, they realized that the first inquiries should be introduced to the students before the scenario video to create a scientific context. Later, they were more realistic about using a new approach. Overall, the teachers perceived that the students liked the learning unit and learned a lot. Thus, according to the teachers, the scenario was a success.

Teachers perceived that it was easy for them to accommodate different opinions and choices, for example, the choices made by the researcher and dentist within the scenario.

According to teachers they had full autonomy in using the scenario in the way they liked, and they had possibilities to comment on the design before implementation during various steps of the process.

Occasionally teachers had a feeling that they were not in control of designing their instruction. It made them a little uncomfortable, for example, when the scenario was ready only a few days before its 
implementation. However, they still trusted the researcher and dentist to develop a proper scenario for their use.

Teachers also highlighted the visual and informative appearance of the co-designed scenario and agreed to the virtual and personal contact with the dentist through video engaged students. The teachers experienced ownership and agency towards the instruction, even though they perceived that they were not in control and their physical and mental effort was not needed during some design steps. Teachers perceived that the career-related instruction was interesting for the students.

\subsection{Students' Perceptions of Relevance, Interest and Scenario Attributes}

The descriptive statistics from the scenario evaluation main categories are presented in Table 5. The categories are further explained in text. Students' answers regarding their interest and scenario attributes from open-ended questions are displayed as quotations in text.

Table 5. Students' scenario evaluation descriptive statistics. $\mathrm{N}=41$.

\begin{tabular}{ccc}
\hline Categories & Mean & Standard Deviation \\
\hline Relevance & 2.33 & 0.77 \\
Individual dimension & 2.41 & 0.76 \\
Societal dimension & 2.36 & 0.71 \\
Vocational dimension (knowledge gain) & 2.75 & 0.62 \\
Vocational dimension (future aspiration) & 1.96 & 0.72 \\
Interest & 2.27 & 0.40 \\
Scenario attributes & 2.99 & 0.41 \\
\hline
\end{tabular}

The students perceived the scenario individually and as socially relevant, but there was variation within the categories. Individually, the students perceived that they could link their new knowledge about the scenario topic and careers to their future needs. However, they did not find the topic personally important, but it was important for learning school subjects. Conversely, the students perceived the topic important for the whole world and the scientific problem was socially relevant. Vocational knowledge and future aspiration divide the students' perceived relevance of the vocational dimension. According to the students, they gained new knowledge about possible careers for them. Moreover, the scenario helped them to understand the skills and responsibilities associated with the career. The students' aspiration to pursue a similar career was low. However, their future studies might be somehow related with the topic in the scenario. Some students perceived they would not need the new knowledge related with the topic, but others thought they might need it if they would have a career in the field: "If I would become a dentist or something similar".

Even though the students' overall interest was not high, it was the scenario itself that aroused their interest. They had already learned a lot about the scientific topic and careers, so they were not interested in learning more about the topic of the scenario. Only a few students gave explicit reasons why: "The career is not interesting"; "I'm not so interested that I would like to know everything about the topic". Nevertheless, students highly appreciated the scenario's appearance. It was easy to follow and understand for the students: "It was a little boring but finely done"; "It was easy-going, and the topic was covered well"; "Easy to follow".

\section{Discussion}

The teachers explained how difficult it is to integrate careers in science education [3] and needed novel educational methods to overcome this challenge. Thus, their goals and interests (cf. [23]) and their need for change [18] led them to co-designing an educational innovation. They wanted to involve the researcher and a real professional in designing the instruction combining science knowledge with the career of a dentist and her explanations about the chemistry issues with teeth. It was important for them to include this information in their local curriculum as proposed in previous research $[64,65]$. 
The teachers experienced a high sense of ownership and agency towards the instruction, even though they were not involved in all phases of the co-design process [13,14]. The results of teachers' high ownership and agency aligns with the students' perception of a successfully implemented co-designed career-related instruction [15].

The teachers highlighted the visual and informative appearance of the co-designed scenario and agreed that the virtual and personal contact with the dentist through video engaged students in following science inquiries. Thus, the design and other ideas of the co-designers were supported [17]. Retrospective interviews revealed that they have continued to use and develop the scenario further. In addition, they have shared it and discussed it with their colleagues. This is a sign of feeling ownership as Pierce et al. [16] argues.

When teachers are free to implement the co-designed scenario and the rest of the learning unit in their own way, it promotes their autonomy and further experiences of agency [21], which is particularly important when the teachers are used to high autonomy in their work [6]. After all, the results of the co-design process show that the teachers participated in all the phases except creating videos for the scenario and career-related activities. However, the teachers need the freedom to change everything in the scenario and learning unit and in this case, they used this possibility a few times when they felt it was necessary. The teachers perceived that it was easy to implement the scenario and it was successful [25]. Nevertheless, in such a co-design process teacher can lose some aspects, for example, feelings of control [20] and autonomy [21], but gain others such as a professional's viewpoint and new knowledge. In the end, the teachers appreciated that the learning unit was relevant and interesting for the students, but they were also interested in the students' perceptions.

The results reveal that the students found that the scenario starting the instruction was relevant for them personally and for society. Their perceived high vocational relevance, particularly with vocational knowledge, suggests that it is possible for this kind of instruction to correct possibly existing career stereotypes $[29,30]$. According to the teachers and students, it seems that the problem assigned to the students personally by the dentist had an impact on students' interest in the following learning activities. Earlier studies confirm that these kinds of real-world connections $[50,51]$ and student-scientist partnership [44,46] are relevant and increase students' interest in science. The results and previous research reveal it is not always easy or possible to create and implement this kind of authentic environment [43]. However, the artificially created interaction between students and professional in the designed instruction helps with the problem of resources and access to experts [47].

Even though the career of a dentist probably was familiar to the students before, the students perceived that they learned more about the skills and responsibilities needed in the career. Thus, career-related instruction gives students new knowledge, not only about scientific topics, but also about careers and needed working life skills and responsibilities in a career. All these raise students' career awareness and gives them accurate perceptions of STEM careers, which is assumed to increase the number of students choosing STEM studies and careers [40]. Considering that generally Finnish secondary school students are not that interested in science studies or science-related careers [66], their future career aspirations were moderate. The students' interest in the scenario was high and it might raise their interest towards learning science.

As said, teachers, but also students, appreciated the scenario's attributes and appearance. Something new and different always arouses interest. Videos, connection with a professional, freedom to choose and create inquiries, and using creativity in reporting results makes science learning relevant and interesting for the students and involves them in scientific processes and decision making [53,54]. Without the career introduction and interaction with the professional, students might learn the same scientific knowledge and skills but lose connections and understanding how and why their knowledge and skills are relevant outside the school context.

This type of career-related instruction helps the students meet professionals working in STEM fields and gives them the opportunity to learn about new and unknown careers or something new about a familiar career [2]. This possibly increases the number of students choosing science 
careers [67], or at least promotes the overall appreciation of science-related careers in society [39]. Even though the connection with the real professional was through videos and not authentic, it made students feel their contribution was valued. Career-related activities also help teachers plan learning units with connections to everyday life and emphasize the link between science and society [31]. The career-related instruction studied in this paper shows a good example of the usefulness of multi-stakeholder cooperation in designing science education.

\subsection{Further Research and Implications}

Co-designing career-related instruction needs more studies, particularly bringing together familiar (peers and colleagues) and unfamiliar (science professionals, researchers, policy makers and educational designers) co-designers with the teachers. More research is also needed focusing on teachers' positioning towards different career-related instructions and design processes to find out if there are variables other than ownership and agency that make the implementation successful. Studies on career-related instruction itself have already been reported but more research is needed to refine the idea of combining scenarios, inquiries and career-related activities.

This case study and future research can give researchers and educators guidelines for connecting science teaching with careers. Moreover, it exemplifies good conditions for co-designing science instruction. The findings will not only have practical implications for introducing the design of a career-related scenario and learning unit, but also practical implications for teachers to understand how to confront and implement innovation in education.

Teachers struggle to find school-industry/community partnerships. Multi-stakeholder cooperation provides them support from researchers, scientific professionals and peers. Once partnerships are established it is easier for the teachers to continue developing more advanced instructions with their partners. However, the teachers need help, time and resources to initiate finding these partners. Projects and studies considering this issue are welcome in the field of science education and in-service teacher training.

\subsection{Limitations}

Although this study provides useful information about co-designing career-related instruction, it has some limitations. Nuances can be lost or misunderstanding the information participants provide can occur during transcription and translation processes. In this study, questionnaire items were translated and checked by multiple researchers. One researcher interviewed the teachers, transcribed and translated quotations to be sure no information was lost. The data was collected from two teachers and their three groups in one school and it is likely that different co-design processes could have emerged among teachers and students with different backgrounds. However, this co-design process and the career-related instruction can be addressed to different contexts without changing it.

The number of participants in this study was small and therefore it is not intended as a case study to generalize the results [56]. There could be more complicated reasons for students' future science-related career aspirations. However, two teachers, three groups and 41 students in a case study, and in the context of the research problem, is adequate to draw conclusions about the co-design process and influence of career-related instruction in students' perceptions of relevance and interest of the science-related career and topics. In addition, multiple data sources and precise analysis and reporting gives other researchers and educators valuable information. Besides, educational intervention can be novel, useful and relevant without fully understanding the underlying affecting mechanisms [68].

\section{Conclusions}

We conclude that combining top-down and bottom-up approaches in the instructional co-design processes results in successful and satisfactory designs for teachers and students. Teacher's ownership and agency are important in co-designing and implementing innovative instructions that promotes students' interest towards science learning. Co-designing career-related science instruction succeeds 
when teachers support the ideas of innovative instruction, critically reflect on successes and failures, feel that the change is necessary, and have control over implementation. Otherwise, it is unlikely that they would adopt such a working method. The critical components of career-related instruction are the lack of resources such as time, materials and peer support, and access to experts. At first, the co-design process requires more effort than planning regular science teaching. However, if co-designing is done effectively with different roles for different designers, it is possible that everyone will benefit from it. Moreover, it is not as time consuming as one might think and well-designed instructions are useful year after year. Once teachers start creating the school-industry/community partnerships, their professional network grows and it becomes much easier to access new experts from different fields. For further opportunities to co-design career-related instruction, we need to find out what the scientists' and teachers' professional goals, interests and motivators are so that they can participate as co-designers.

In career-related instruction, students recognize scientific problems and have the possibility to become interested in the covered science and health topics. Students gain a lot of new knowledge about careers which corrects possibly existing stereotypes, yet their future career aspirations may remain low in individual cases. Therefore, career-related instruction should concentrate on emphasizing the perceived individual and societal relevance of the topic and introduced careers for the student. Thus, the instruction can have longer lasting and more meaningful effects for the students' future, enabling students to see the connections between careers, topics, science studies, and their personal and professional aspirations later in life. Co-designed scenarios might attract students and give them possibilities to acquire this new knowledge. Achieving the goal of supporting students' future career aspirations in science is more challenging through short interventions. However, using career-related instruction in the long term increases students' realistic science-related career awareness and furthers their aspirations to pursue those fields. Furthermore, teachers experiencing ownership and agency towards co-designing such career-related instruction will enable more careers to be introduced in science education in the future.

Author Contributions: Conceptualization, A.S., S.K. and T.K.; Methodology, A.S., S.K. and T.K.; Formal analysis, A.S.; Investigation, A.S., Writing—original draft preparation, A.S.; Writing-review and editing, A.S., S.K. and T.K.

Funding: This project has received funding from the European Union's Horizon 2020 Research and Innovation Programme under grant agreement No 665100.

Conflicts of Interest: The authors declare no conflict of interest.

\section{References}

1. Cleaves, A. The formation of science choices in secondary school. Int. J. Sci. Educ. 2005, 27, 471-486. [CrossRef]

2. Maltese, A.V.; Tai, R.H. Pipeline persistence: Examining the association of educational experiences with earned degrees in STEM among US students. Sci. Educ. 2011, 95, 877-907. [CrossRef]

3. Salonen, A.; Kärkkäinen, S.; Keinonen, T. Career-related instruction promoting students' career awareness and interest in science learning. Chem. Educ. Res. Pract. 2018, 19, 474-483. [CrossRef]

4. Avalos, B. Teacher professional development in teaching and teacher education over ten years. Teach. Teach. Educ. 2010, 27, 10-20. [CrossRef]

5. Blonder, R.; Mamlok-Naaman, R.; Hofstein, A. Increasing science teachers ownership through the adaptation of the PARSEL modules: A "bottom-up" approach. Sci. Educ. 2008, 19, 285-301. [CrossRef]

6. Eteläpelto, A.; Vähäsantanen, K.; Hökkä, P. How do novice teachers in Finland perceive their professional agency? Teach. Teach. 2015, 21, 660-680. [CrossRef]

7. Van Driel, J.; Beijaard, D.; Verloop, N. Professional development and reform in science education: The role of teachers' practical knowledge. J. Res. Sci. Teach. 2001, 38, 137-158. [CrossRef]

8. Ogborn, J. Ownership and transformation: Teachers using curriculum innovations. Phys. Educ. 2002, 47, 142-146. [CrossRef]

9. Priestley, M.; Biesta, G. Reinventing the Curriculum: New Trends in Curriculum Policy and Practice; Bloomsbury Academic: London, UK, 2013. 
10. Könings, K.; Seidel, T.; van Merriënboer, J. Participatory design of learning environments: Integrating perspectives of students, teachers, and designers. Instr. Sci. 2014, 42, 1-9. [CrossRef]

11. Snitynsky, R.; Rose, K.; Pegg, J. Partnering teachers and scientists: Translating carbohydrate research into curriculum resources for secondary science classrooms. J. Chem. Educ. 2019, 96, 685-690. [CrossRef]

12. Ng, W.; Fergusson, J. Technology-enhanced science partnership initiative: Impact on secondary science teachers. Res. Sci. Educ. 2019, 49, 219-242. [CrossRef]

13. Voogt, J.; Laferrière, T.; Breuleux, A.; Itow, R.; Hickey, D.; McKenney, S. Collaborative design as a form of professional development. Instr. Sci. 2015, 43, 259-282. [CrossRef]

14. Ketelaar, E.; Beijaard, D.; Boshuizen, H.; den Brok, P. Teachers' positioning towards an educational innovation in the light of ownership, sense-making and agency. Teach. Teach. Educ. 2012, 28, 273-282. [CrossRef]

15. Ketelaar, E.; Beijaard, D.; den Brok, P.; Boshuizen, H. Teachers' implementation of the coaching role: Do teachers' ownership, sensemaking, and agency make a difference? Eur. J. Psychol. Educ. 2013, 28, 991-1006. [CrossRef]

16. Pierce, J.; Kostova, T.; Dirks, K. Toward a theory of psychological ownership in organizations. Acad. Manag. Rev. 2001, 26, 298-310. [CrossRef]

17. Breiting, S. Mental ownership and participation for innovation in environmental education and education for sustainable development. In Participation and Learning; Reid, A., Jensen, B., Nikel, J., Simovska, V., Eds.; Springer: Dordrech, The Netherlands, 2008; pp. 159-180.

18. Ketelaar, E. Teachers and Innovations: On the Role of Ownerships, Sense-Making and Agency. Ph.D. Thesis, Technische Universiteit Eindhoven, Eindhoven, The Netherlands, 2012. [CrossRef]

19. Saunders, M.; Alcantara, V.; Cervantes, L.; del Razo, J.; López, R.; Perez, W. Getting to Teacher Ownership: How Schools Are Creating Meaningful Change; Annenberg Institute for School Reform, Brown University: Providence, RI, USA, 2017.

20. Konopasky, A.W.; Sheridan, K.M. Towards a diagnostic toolkit for the language of agency. Mind. Cult. Act. 2016, 23, 108-123. [CrossRef]

21. Allen, C.D.; Penuel, W.R. Studying teachers' sensemaking to analyze teachers' responses to professional development focused on new standards. J. Teach. Educ. 2015, 66, 136-149. [CrossRef]

22. Metcalfe, J.; Greene, M. Metacognition of agency. J. Exp. Psychol. Gen. 2007, 136, 184-199. [CrossRef]

23. Vähäsantanen, K.; Hökkä, P.; Eteläpelto, A.; Rasku-Puttonen, H.; Littleton, K. Teachers' professional identity negotiations in two different work organisations. Vocat. Learn. 2008, 1, 131-148. [CrossRef]

24. Edwards, A. Recognising and realising teachers' professional agency. Teach. Teach. 2015, 21, 779-784. [CrossRef]

25. Marshall, B.; Drummond, M. How teachers engage with assessment for learning: Lessons from the classroom. Res. Pap. Educ. 2006, 21, 133-149. [CrossRef]

26. Clarke, D.; Hollingsworth, H. Elaborating a model of teacher professional growth. Teach. Teach. Educ. 2002, 18, 947-967. [CrossRef]

27. European Commission. Challenging Futures of Science in Society. Emerging Trends and Cutting-Edge Issues; The Masis Report; European Commission: Brussels, Belgium, 2009.

28. European Commission. Science Education for Responsible Citizenship; European Commission: Brussels, Belgium, 2015.

29. Miller, D.I.; Eagly, A.H.; Linn, M.C. Women's representation in science predicts national gender-science stereotypes: Evidence from 66 nations. J. Educ. Psychol. 2015, 107, 631-644. [CrossRef]

30. Salonen, A.; Hartikainen-Ahia, A.; Hense, J.; Scheersoi, A.; Keinonen, T. Secondary school students' perceptions of working life skills in science-related careers. Int. J. Sci. Educ. 2017, 39, 1339-1352. [CrossRef]

31. Christidou, V. Interest, attitudes and images related to science: Combining students' voices with the voices of school science, teachers, and popular science. Int. J. Environ. Sci. Educ. 2011, 6, 141-159.

32. Schütte, K.; Köller, O. Discover, understand, implement, and transfer': Effectiveness of an intervention programme to motivate students for science. Int. J. Sci. Educ. 2015, 37, 2306-2325. [CrossRef]

33. Cohen, C.; Patterson, D. Teaching Strategies that Promote Science Career Awareness; Northwest Association for Biomedical Research: Seattle, WA, USA, 2012; Available online: https:/www.nwabr.org/sites/default/files/ pagefiles/science-careers-teaching-strategies-PRINT.pdf (accessed on 4 September 2019).

34. Kang, J.; Keinonen, T. The effect of inquiry-based learning experiences on adolescents' science-related career aspiration in the Finnish context. Int. J. Sci. Educ. 2018, 39, 1669-1689. [CrossRef] 
35. Lavonen, J.; Gedrovics, J.; Byman, R.; Meisalo, V.; Juuti, K.; Uitto, A. Students' motivational orientations and career choice in science and technology: A comparative investigation in Finland and Latvia. J. Balt. Sci. Educ. 2008, 7, 86-102.

36. Potvin, P.; Hasni, A. Interest, motivation and attitude towards science and technology at K-12 levels: A systematic review of 12 years of educational research. Stud. Sci. Educ. 2014, 50, 85-129. [CrossRef]

37. DeWitt, J.; Archer, L. Who aspires to a science career? A comparison of survey responses from primary and secondary school students. Int. J. Sci. Educ. 2015, 13, 2170-2192. [CrossRef]

38. Childs, P.; Hayes, S.; O'Dwyer, A. Chemistry and everyday life: Relating secondary school chemistry to the current and future lives of students. In Relevant Chemistry Education-From Theory to Practice; Eilks, I., Hofstein, A., Eds.; Sense Publishers: Rotterdam, The Netherlands, 2015; pp. 33-54.

39. Goodrum, D.; Druhan, A.; Abbs, J. The Status and Quality of Year 11 and 12 Science in Australian School; Australian Academy of Science: Canberra, Australia, 2012.

40. Osborne, J.; Collins, S. Pupils' views of the role and value of the science curriculum: A focus group study. Int. J. Sci. Educ. 2001, 23, 441-467. [CrossRef]

41. Tai, R.; Liu, C.; Maltese, A.; Fan, X. Planning early for 'careers in science'. Science 2006, 312, $1143-1144$. [CrossRef] [PubMed]

42. Sadler, T.D. Situating socio-scientific issues in classrooms as a means of achieving goals of science education. In Socio-Scientific Issues in the Classroom. Teaching, Learning and Research; Sadler, T.D., Ed.; Springer: Dordrecht, The Netherlands, 2011; pp. 1-9.

43. Falloon, G. Forging school-scientist partnerships: A case of easier said than done? J. Sci. Educ. Technol. 2013, 22, 858-876. [CrossRef]

44. Hellgren, J.M. Students as Scientists: A Study of Motivation in the Science Classroom. Ph.D. Thesis, Umeå Universitet, Umeå, Sweden, 2016.

45. Peker, D.; Dolan, E. Helping students make meaning of authentic investigations: Findings from a student-teacher-scientist partnership. Cult. Stud. Sci. Educ. 2012, 7, 223-244. [CrossRef]

46. Houseal, A.K.; Abd-El-Khalick, F.; Destefano, L. Impact of a student-teacher-scientist partnership on students' and teachers' content knowledge, attitudes toward science, and pedagogical practices. J. Res. Sci. Teach. 2014, 51, 84-115. [CrossRef]

47. Evans, C.; Abrams, E.; Rock, B.; Spencer, S. Student/scientist partnerships: A teacher's guide to evaluating the critical components. Am. Biol. Teach. 2001, 63, 318-323. [CrossRef]

48. Finnish National Board of Education. National Core Curriculum for Basic Education 2004; Finnish National Board of Education: Helsinki, Finland, 2004.

49. Finnish National Board of Education. National Core Curriculum for Basic Education 2014; Finnish National Board of Education: Helsinki, Finland, 2014.

50. Cigdemoglu, C.; Geban, O. Improving students' chemical literacy levels on thermochemical and thermodynamics concepts through a context-based approach. Chem. Educ. Res. Pract. 2015, 16, 302-317. [CrossRef]

51. Rannikmae, M.; Teppo, M.; Holbrook, J. Popularity and relevance of science education literacy: Using a context-based approach. Sci. Educ. 2010, 21, 116-125.

52. Bolte, C.; Streller, S.; Holbrok, J.; Rannikmae, M.; Hofstein, A.; Mamlook-Naaman, R. Introduction into the PROFILES Project and its Philosophy. In Inquiry-Based Science Education in Europe: Reflections from the PROFILES Project; Bolte, C., Holbrook, J., Rauch, F., Eds.; Freie Universität Berlin: Berlin, Germany, 2012; pp. 31-41.

53. Holbrook, J.; Rannikmae, M. Contextualisation, de-contextualisation, re-contextualisation-A science teaching approach to enhance meaningful learning for scientific literacy. In Contemporary Science Education; Eilks, I., Ralle, B., Eds.; Shaker Verlag: Aachen, Germany, 2010; pp. 69-82.

54. Brossard, D.; Lewenstein, B.; Bonney, R. Scientific knowledge and attitude change: The impact of a citizen science project. Int. J. Sci. Educ. 2005, 27, 1099-1121. [CrossRef]

55. McKenney, S.; Reeves, T. Conducting Educational Design Research; Routledge: London, UK, 2019.

56. Cohen, L.; Manion, L.; Morrison, K. Research Methods in Education; Taylor \& Francis Group: Abingdon-on-Thames, UK, 2011. 
57. Kang, J.; Keinonen, T.; Simon, S.; Rannikmäe, M.; Soobard, R.; Direito, I. Scenario evaluation with relevance and interest (SERI): Development and validation of a scenario measurement tool for context-based learning. Int. J. Sci. Math. Educ. 2019, 17, 1317-1338. [CrossRef]

58. Kotkas, T.; Holbrook, J.; Rannikmäe, M. A theory-based instrument to evaluate motivational triggers perceived by students in stem career-related scenarios. J. Balt. Sci. Educ. 2017, 16, 836-854.

59. Stuckey, M.; Mamlok-Naaman, R.; Hofstein, A.; Eilks, I. The meaning of 'relevance' in science education and its implications for the science curriculum. Stud. Sci. Educ. 2013, 49, 1-34. [CrossRef]

60. McIntosh, M.J.; Morse, J.M. Situating and constructing diversity in semi-structured interviews. Glob. Qual. Nurs. Res. 2015, 2. [CrossRef] [PubMed]

61. Elo, S.; Kyngäs, H. The qualitative content analysis process. J. Adv. Nurs. 2008, 62, 107-115. [CrossRef] [PubMed]

62. Struckman, C.; Yammarino, F. Organizational change: A categorization scheme and response model with readiness factors. In Research in Organizational Change and Development; Emerald Group Publishing Limited: Bingley, UK, 2003; Volume 14, pp. 1-50.

63. Fredricks, J.A.; McColskey, W. The measurement of student engagement: A comparative analysis of various methods and student self-report instruments. In Handbook of Research on Student Engagement; Christenson, S.L., Reschly, A.L., Wylie, C., Eds.; Springer Science + Business Media: New York, NY, USA, 2012; pp. 763-782.

64. Andersen, L.; Ward, T.J. Expectancy-value models for the STEM persistence plans of ninth-grade, high-ability students: A comparison between Black, Hispanic, and White students. Sci. Educ. 2014, 98, 216-242. [CrossRef]

65. Holmegaard, H.; Madsen, L.; Ulriksen, L. To choose or not to choose science: Constructions of desirable identities among young people considering a STEM higher education programme. Int. J. Sci. Educ. 2014, 36, 186-215. [CrossRef]

66. Bybee, R.; McCrae, B. Scientific literacy and student attitudes: Perspectives from PISA 2006 science. Int. J. Sci. Educ. 2011, 33, 7-26. [CrossRef]

67. Organization for Economic Co-operation and Development (OECD). PISA 2015 Results (Volume I): Excellence and Equity in Education; PISA, OECD Publishing: Paris, France, 2016.

68. Bielaczyc, K. Informing design research: Learning from teachers' designs of social infrastructure. J. Learn. Sci. 2013, 22, 258-311. [CrossRef] 